\title{
Overcoming Conflict of Interest-Based Local Culture Values in Management of Village Fund Institution
}

\author{
Subhan Purwadinata ${ }^{1^{*}}$ Agus Suman $^{2}$ Susilo $^{3}$ Asfi Manzilati ${ }^{4}$ \\ 1,2,3,4 Brawijaya University \\ *Corresponding author. Email: 123adinata@gmail.com
}

\begin{abstract}
The purpose of this study is to uncover the principal-agent behavioural problem caused by conflicts of interest. The focus of this research is to find answers to behavioural problems that occur between principal and agent in the village fund management institutions. The method design uses an interpretive paradigm approach by applying a principal-agent theory based on interests. Research approach through qualitative methods by conducting in-depth interviews with several competent speakers on village fund management institutions and Sumbawa cultural experts. The research shows that there are conflicts of interest in the use of village fund by agent who behave opportunistically and weaken the agent confidence in him, leading to self-behaviour, legalized fraud and conscience and powerlessness of agent in fund management institution. The solution of the problem of use can be overcome by the Sumbawa approach of cultural value, namely the behaviour of the improvement village in terms of mutual respect value and mutual trust value. It is also strengthened by the goal to safety value and value of justice and value of balance in the value system of balancing cultural Sumbawa to improve institutionally the relations between village communities and village leader. The conclusion of this research shows that the problem of conflict of interest in the management of village fund facility can be overcome by using the Sumbawa cultural value in strengthening the role of the village fund management institution.
\end{abstract}

Keywords: Conflict of interest, Management of Village fund, Village fund

\section{INTRODUCTION}

In the past, rural conditions were sociologically and culturally different from the city, because they showed a lagging distance far from the city [1]. The emergence of Law No. 6/2014 on Village in Indonesia has been able to move entities based on origins in village (recognition) on the recognition of local values that already exist in village that can strengthen the role of village institutions. The regulation strengthens the paradigm shift in village regulation which forms the basis of the village fund management institution as outlined in Village Minister Regulation (Permendes) No.19 2017 concerning the priority of the use of village fund which eventually becomes a national policy. As a result of this policy, the central government poured large amounts of funds into village with a value of approximately one billion IDR per village.

The issue of agency is a contract between the principal as the owner of the principal and agent as the management who manages. Moral hazard is an agent decision or action that emphasizes satisfaction and ignores principal interests or satisfaction [2]. In uncovering the problem, the researcher conducted a study in Kukin village, North Moyo sub district, Sumbawa regency, which was one of the disadvantaged villages in Eastern Indonesia (KTI). Village fund which eventually lead to moral hazard in the form of agent who tend to be self-interested and not transparent in the village fund management institutions.

This research seeks to solve the problems that occur in the relationship between the principal and the agent in the village fund management institution using the Sumbawa local wisdom value approach in shaping the behavior of Sabalong Desa (improving the village) in the order of kerik salamat (towards safety) value and sabalong samalewa (fair, harmonious and balanced) as a framework for solving problems arising from these relationships. The role of values governance is actively involved directly in guiding principal and agent in institutional management of village fund, but its nature provides an overview and form of behaviour that contains advice on how to behave ideally carried out by the agent (village leader) and principal (village community) as the main actors in the village fund management institution. 
The second part of this study describes qualitative approach and method as instrument to answer problem and the third part explain the meaning of local culture values in the issues of principal (village community) and agent (village leader) interests in village fund management institution.

\section{METHODS}

Based on preliminary research and finding problems to be answered, qualitative research methods are used [3]. As a problem solving, it uses the symbolic interaction approach in the interpretive paradigm by finding snowball indepth interviews on informants, especially in the interaction between individual village communities involved in village fund management institutions in the Sumbawa Kukin village. Data collection was carried out in two ways, namely the first unstructured interview technique for the main informants, the village leader, village secretary, Chair of the Village Consultative Body (Badan Permusyawaratan Desa/BPD) and Sumbawa cultural experts and village communities. Second, the field observation technique by placing the researcher in the position of the researched party and participating in behavioral relations activities between the principal (village community) and the agent (village leader) in the village fund management institution.

Test the validity of the data by means of interpreting the same phenomenon from result interview data (emic data) input obtained from the informant and making the research findings as the basis for giving birth to public opinion [4]. Then test the reliability of the data by evaluating the findings in the study of the actual behavior of an informant or that view supports each other (intercoder reability) by asking other observers to review the behavior of an informant so that it can reduce the possibility of errors in reading the collected data. The method of analyzing data by copying (transcribing) is to copy the recorded conversations between informants and researchers to become transcripts of data in the form of symbols that appear when informants are interviewed such as laughing, crying or normal is an important part to be analyzed. Furthermore, becoming familiar with the data is by carefully examining the transcript, coding, which is creating a category while marking the selected data in accordance with the focus of the study. To analyze data using the main premise Udehn [5], namely: (1) Humans act on something based on the meanings that are in something for them. (2) The meaning comes from someone's social interaction with other people. (3) These meanings are perfected when the process of social interaction takes place.

\section{RESULTS AND DISCUSSION}

This study shows some interesting findings to be discussed, dominance interested of the village leader movement and their supporters, which contributes to the legalized fraud in management of village fund. For this reason, an alternative solution to overcome this is to use the meaning of the agreed local culture values described in this section

\subsection{Self Interest and Supporters of the Village Leader Dominate the Joint Village Fund Management}

Agency conflicts that often occur between village governments institutionally (village leader, BPD and others) as agent with village communities as principal are triggered by the existence of these basic characteristics. The village leader in implementing village fund management tends to prioritize personal interests rather than village interests. The results of this study indicate that there is a tendency for conflict between fellow agent in this case the village leader and the head of the BPD, then fellow principals (community members of the village leader and the village community again the village leader). On the one hand the agent (village leader) has confirmed that he has provide the best service for the principal (village community).

Paying attention to the word "lazy over" directed at BPD by village people who are pro village leaders always gives full support to them until they dare to say that the BPD does not work at all, meaning that information received by the village community is a strong reason for the principal (village community) suppress agent in this case BPD so that there is a perception of the future (bounded rationality).

Noting the statement that gave rise to the phrase "I asked to fight" asserted that the relationship between agent also experienced differences in interests because in the BPD perception that it would be impossible to criticize when still in the work process but the village leader perception that the BPD was always watching jointly the work to find out where the shortcomings are. A new understanding of agent in economics [6] agrees that rational, behavioral drivers based on personal desires are truly rare except for an intentional (policy) effort to introduce that this is a responsibility.

This behavior is in the village leader especially in the use of village fund which are ideally used for the welfare of the village community, but in allocating this fund the role becomes changed and even attempts to take the opportunity that comes to him. This shows that there is no strong commitment from the personal village institutions to fight for the interests of the village community. Village fund in the context of implementation are synonymous with political space so 
that they are vulnerable to being misused, because the space has consequences that arise into an agreement of interaction between village fund management actors because the village did not get a large amount of funds today, such as village fund management practices. In several periods it was vulnerable to conflicts of interest and gave rise to several phenomena of bad practices resulting from improper interpretations of relations between village leaders and village communities.

\subsection{The Interest of the Village Leader Causes Legitimate Fraud in Village Fund Management}

The behavior of the village leader as an ideal agent always puts forward the policy for the welfare of the village community as principal because he has obtained a full mandate from the village community, but in using their village fund institutionally seizes the opportunity to commit fraud as if legalized by the current rules. Such behavior is called "corruption" behavior which is refined by fraudulent language that is legalized because it is sheltered under a rule that seems to be a space of justification for this behavior.

The behavior of the village leader as an ideal agent always puts forward the policy for the welfare of the village community as principal because he has obtained a full mandate from the village community, but in using their village fund institutionally seizes the opportunity to commit fraud as if legalized by the current rules. Such behavior is called "corruption" to find out more about village fund institutional management.

Related to the results of this study, the opinion of the two experts above is justified as the reality in the findings of this study that the high authority of the village leader seemed to close the space for others to influence him even the chairman of the BPD was scolded by the village leader. This indicates that there has been an abuse of power to influence others, so that when it is effective the principal (village community) will feel reluctant to give reprimand, advice because there is a sense of "fear" that is quite excessive because it is based on feelings of respect for position.

The researcher noticed that in this condition there was a tendency for the village leader as an agent to want to justify because actually the opportunist behavior he had and the desire to win on his own basically answered that the behavior of the village chief opened the curtain to open a cheating room even though turbulence remained in his heart who is strong enough to commit fraud in real terms.

The results of this study confirm that the knowledge or beliefs or perceptions of the village leader know very well that morally corrupt and opportunist behavior is a form of behavior that is prohibited by Islam in line with the basic values of sabalong samalewa (value of justice, value harmony and balance value) and toward safety values (kerik selamat) upheld in the context of the Sumbawa people repair village. Thus, it can be concluded that there is actually an interesting attraction in the village leader actual knowledge, beliefs and perceptions even though the wrong behavior is carried out because inwardly he will give a signal that is contrary to his sacred heart purity because it is a limitation and weakness in the village leader.

\subsection{The Meaning of the Value of Repair Village (Sabalong Desa) in Deciphering the Issues of the Uphold of the Village Leader Interest in Using Village Fund}

The various phenomena that appear to be, according to the culture of Sumbawa society is a very distorted one, and in the culture of Sumbawa people someone who is only selfish without thinking of others is a behavior that is very contrary to the values possessed by samawa sabalong samalewa. These values have a very clear benchmark derived from Islamic teachings as the religion of the Sumbawa community. Personal interest in the meaning of the value of justice in the practice of village fund management in the village of Kukin Sumbawa leaves many problems both administratively and in implementation even in reporting that is almost the same as other village in the Sumbawa district.

This is due to an indication of the materialist nature embedded in the village leader as the executor and accountability of village fund in Kukin village. In addition, the communication built with the village community is still not transparent. This shows a tendency that the relationship that is built is not healthy between the village leader and the community. The nature reflected in the village leader is more likely to prioritize personal interests which will lead to the loss of the value of justice in the village leader as a representative of the village community appointed as the leader in the village. It can be assumed that personal interests or the interests of partners or camps that always support the village leader are indeed above the interests of the community in the village. This fact if it continues to be carried out then what happens is betrayal of the village community. In this case it will shape the opportunistic behavior of the village leader in carrying out his obligations, which is contrary to the Sumbawa culture.

The findings of this study are that there is a symbol of self-interest from the village leader in carrying out his obligations as an agent, because in the context of Sumbawa culture this is very contradictory because in the view of Samawa culture that is based on sabalong samalewa (value of justice, value harmony and balance value), ideally it must be owned and must exist within the individual Sumbawa community. Based on the findings of this study that in the principal relationship (village communities and agent (village leader) institutionally self behavior and supporting communities have emerged 
which lead to the dominance of institutional management of village fund because of personal interests which cause legal fraud, conscience and powerlessness of the village community.

The value of justice contained in samawa sabalong samalewa (value of justice, value harmony and balance value) is a value that must be owned by every community or person who calls himself Sumbawa. In the life of the just word, it is necessary to keep growing, because it is fair in a verse which means that before we do good, we should first be fair. This explains that fair is not only intended for others but justice is also necessary for oneself and those who are fair will always be able to separate emotions and ratios, love and envy and honesty, so that they always have the commitment to lead to the path of truth.

The village leader as the representative of the village community must fight according to his duties as a channel for the aspirations of the village community so that the interests of the village community are prioritized. The village leader is tau samawa (Sumbawa people), where in Zulkarnain [7] tau samawa (Sumbawa people) are all communities inhabiting tana samawa (samawa earth), no exception. Someone who feels himself to know samawa (Sumbawa people) must uphold the noble values of the Sumbawa community. If there is opposition, they are said not to be tau samawa (Sumbawa people) even though they are in fact tau samawa (samawa people).

Harmony aims to establish togetherness between village leaders and village communities. The reality is that the village leader establishes good togetherness with the government in terms of lying to the village community. This they use to cheat with other village institutions to prosper their lives without thinking about the village community, which will cause legalized fraud, or another name is corruption. The Sumbawa culture in the pantun also explains this, where they say "mutual to belief" which means that they remind each other.

Balance must also be in line with carrying out development in Sumbawa, because in building Sumbawa the balance must be in all aspects of life both in the life of the world and the hereafter, as stated in the samawa sabalong malaewa or life goes in rhythm. Despicable things that violate religious provisions, especially Islam, will never happen. Someone who feels himself to know samawa (Sumbawa people) must have good morals and a soul that is clean of despicable deeds. This moral when we look at it in terms of the culture of the Sumbawa people, then in the samawa sabalong samalewa (value of justice, value harmony and balance value) motto, that moral has become a unity with the motto.

The balance value, which is one of the values contained in samawa sabalong samalewa (value of justice, value harmony and balance value), is used by the Sumbawa community to assess all behavior can be controlled by balance. Balance must exist in the aspects of life for every being, because when the balance is extinct, there is chaos in life. In the culture of Sumbawa people, corruption has never existed because this is detrimental to others.

The results of this study indicate a symbol of behavior that is "fraudulent" has been carried out by the village leader and his supporters in accordance with the research results are forced interests, as is the reality in the findings of this research The BPD was scolded by the village leader. This indicates that there has been an abuse of power to influence others, so that when it is effective the principal (village community) will feel reluctant to give reprimand, advice because there is a sense of "fear" that is quite excessive because it is based on feeling respect for the position in accordance with the research results that legalized fraud occurs as a result of self-interest. Conscientious upheaval the village leader is only a motive inherent in behavior that at least cheating is not done massively in taking advantage of opportunities that exist in the village fund management institutions. Then the framework for resolving the problem can be solved by the Sabalong Desa (repair village) behavior approach in the governance of the value of the local wisdom of the Sumbawa community. This is confirmed in more detail in the following scheme: 


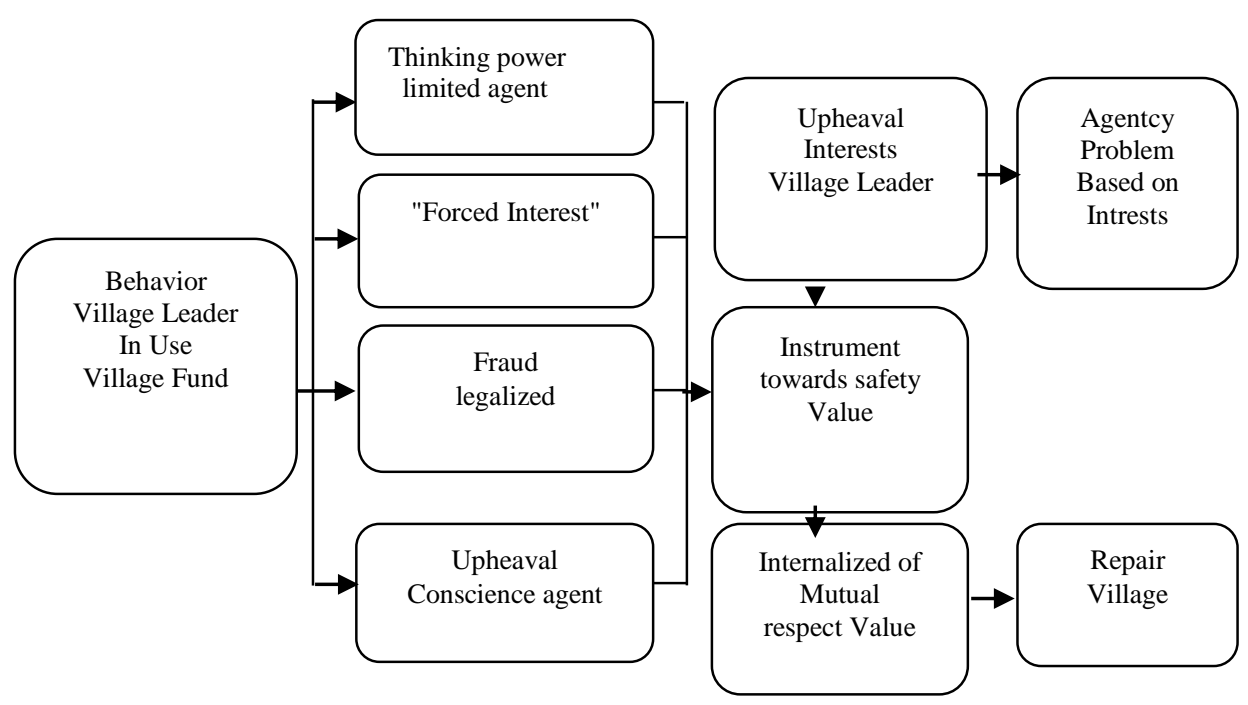

Figure 1. Map of Sabalong Village Value Findings in Explaining the Issues of the Village Leader Upheaval in Using Village fund

\section{CONCLUSION}

It was revealed that there was a problem of principalagent behavior as a cause of conflict of intest in village fund management institutions and problem of conflict of interest in the management of village fund facility can be overcome by using the Sumbawa cultural value in strengthening the role of the village fund management institution. Agent of opportunistic behavior in the form of self determination and self interest which can be overcome by the Sumbawa local cultural value approach mutual trust value and mutual respect value in the value system towards safety and the value of justice and the value of balance in the value system of sabalong samalewa (balanced in harmony and fair) to strengthen the village fund management institutions. Research propositions are the problem of principals and agent that cannot be resolved only by prioritizing economic factors, closeness and interests, but need an intensive approach to behavior change to reduce the occurrence of moral hazard for institutional sustainability.

\section{ACKNOWLEDGMENT}

The authors express their utmost gratitude to the Lembaga Pengelola Dana Pendidikan (LPDP) through BUDI-DN to the Ministry of Finance of the Republic of Indonesia as sponsor or funder in the seminar and publication of this article.

\section{REFERENCES}

[1] H. Antlöv, Civic Engagement in Local Government Renewal in Indonesia, in Hans Antlov, et.al, Citizen Participation in Local Governance: Experiences from Thailand, Indonesia, and the Philippines (Manila: IPD for Logolink Southeast Asia).1971. 2004.

[2] H. Blumer, Symbolic Interaction. Dalam J.P. Spadley. Cultural and Cognition. San Fransisco: Chandler Publisihing Company, 1992.

[3] Meador, J. E., \& Skerratt, S.. On a uni fi ed theory of development : New institutional economics \& the charismatic leader. Journal of Rural Studies, 53, 2017, pp.144-155.

[4] C. Michael, Jensen and H. M. William, Theory of the Firm: Managerial Behavior, Agentcy Costs and Ownership Structure, Journal of Financial Economics, Vol. 3, No. 4, 1976, pp. 305-360.

[5] L. Udehn, Methodological Individualism: Background, History and Meaning, London and New York : Roudledge. 2001

[6] P. R. Ulin, T. R. Elizabeth, E. T. Elizabeth, T. Mc, Erin Qualitative Methods; Applied Reseach in Sexual and Reproductive Health. Family Health International. North Carolina. USA. Hal V. 2002

[7] A. Zulkarnain, Characteristics of Leadership in Custom and Rappang Tana Samawa. First printing. Sumbawa Besar. Tana Samawa Customary Institution. 2008 